
breast tumours? Science 1988;240:1795-6.

11 Gusterson BA, Machin LG, Gullick WJ, et al. C-erbB-2 expression in benign and malignant breast disease. Br $\mathcal{A}$ Cancer 1988;58:543-8.

12 Slamon DJ, Goldolphin W, Jones LA, et al. Studies of HER-2/neu proto-oncogene in human breast and ovarian cancer. Science 1989;244:707-12.

13 Borg A, Linell F, Idvall I, et al. HER2/neu amplification and comedo type breast carcinoma. Lancet 1989;i:1268-9.
14 Lammie GA, Barnes DM, Millis RR, Gullick WJ. An immunohistochemical study of the presence of c-erbB-2 protein in Paget's disease of the nipple. Histopathology (in press)

Cardiff RD. Cellular and molecular aspects of neoplastic progression in the mammary gland. Eur $\mathcal{Y}$ Cancer Clin Oncol 1988:24:15-20.

16 Clark GM, Dressler LG, Owens MA, et al. Prediction of relapse or survival in patients with nodenegative breast cancer by DNA flow cytometry. $N$ Engl 7 Med 1989;320:627-33.

17 O'Reilly SM, Camplejohn RS, Barnes DM, Millis RR, Richards MA. DNA index, S-phase fraction, histological grade and prognosis in breast cancer. $\mathrm{Br} \mathcal{F}$ Cancer (in press).

\title{
Law, politics, and the GPs' contract
}

\author{
GMSC won't break law but will identify contract defects
}

General practitioners throughout Britain are angry - with $\mathrm{Mr}$ Kenneth Clarke and with their leaders. A new contract that was rejected by a large majority in a national ballot of general practitioners has been imposed on them by the Secretary of State for Health. ${ }^{1} \mathrm{He}$ has acted within the law, and the General Medical Services Committee is to keep its opposition to the new contract within the law (p 1107). Doctors' anger is, however, qualified by the recognition by general practitioners that on this issue the public is confused and by no means totally supportive. Some of the changes in the new contract, such as making it easier for patients to change doctors and health checks for the elderly, seem good ideas to the average citizen. Last week the GMSC examined the law and the politics of the imposed contract and advised its angry constituents to be patient and not to embark on any sort of industrial action -it would only harm patients. So has $\mathrm{Mr}$ Clarke "won"? And what happens next?

General practitioners know but most of the public still seems unaware that this dispute predates the white paper Working for Patients. ${ }^{2}$ The new general practitioner contract is based on an earlier white paper, Promoting Better Health, which appeared in $1987 . .^{3}$ Confidential negotiations between the Department of Health and general practitioner leaders on the proposals for a new contract began even earlier than that and continued until May of this year, when the GMSC negotiators reluctantly agreed to commend to general practitioners a new form of contract as "the best they could achieve." At the time their chairman, Dr Michael Wilson, told $\mathrm{Mr}$ Clarke that it was by no means certain that general practitioners would agree to the deal. When they were consulted most of the general practitioners rejected the new contract; the secretary of state refused to reopen negotiations; and having "consulted" with the profession as the law requires, on 16 October he announced that he would be laying regulations on the contract before parliament this session and that it would come into force in April 1990.41 With the government's large parliamentary majority there is little doubt that Mr Clarke will achieve this objective.

Why are general practitioners so angry? Firstly, they really do not like the new contract. They resent the secretary of state's negotiating tactics and having imposed on them substantial changes to their working conditions and the way they are paid. They resent the emphasis on numbers of patients and object to much of the detail such as the requirement to measure patients' heights, which is tantamount to clinical direction. Secondly, many general practitioners cannot understand why the GMSC is continuing to negotiate with the Department of Health about a contract that they have resoundingly rejected. As a result some seem to have lost faith in their negotiators - $\mathbf{a}$ feeling evidenced by a proposal of "no confidence" in Dr Wilson at the meeting of the GMSC last week, though the committee supported him by a vote of 47 to 19.

Mr Clarke's intransigence was signalled well ahead, and the BMA and the GMSC have had time to consider the choices available to them. The report of the alternative strategies working party (regrettably leaked to the Sunday press, in the fashion of the times) was discussed at length by the committee last week, but the conclusion was inevitable. Resignation from the NHS is the last resort, and it would succeed as a strategy only if most doctors would be willing to support the move. One suggestion, unilateral variation in the contract by doctors, would be illegal - and if organised by the BMA could lead to legal redress for incitement to breach of contract. In the world of industrial disputes as currently defined doctors have no practicable way of attacking their employer (strictly, the party to their contracts) without harming patients.

So the committee has recommended patience. It will continue its efforts to modify further the regulationsimprovements have already been achieved. The contract and the regulations that will impose it will be "subjected to a careful scrutiny in order to provide the basis for a published report on the defects and the deficiencies resulting from the imposition."

This means, in effect, that general practitioners' representatives recognise that they have had to retreat after this battle but that they are not by any means defeated. Time is on the side of the medical profession. Governments come and go and so do health ministers: patients and doctors remain. Within two years this government will want to go into the next election campaign with some appearance of having solved the problems of the NHS. At this stage all it has managed is to antagonise most general practitioners, having already antagonised many hospital doctors, and the NHS review has yet to go through parliament.

We hope, however, that talk in the press of battles and victories can now be forgotten. Like the partners in a marriage (before the days of divorce) the doctors in the NHS and the government have got to go on working together; that means talking together and achieving some accommodation. $\mathrm{Mr}$ Clarke will recognise this, sooner or later.

Deputy Editor, $B M \mathcal{F}$

TONY SMITH

1 Anonymous. Mr Clarke claims contract is "good news for GPs." Br Med $\mathcal{f}$ 1989;299:1035. 2 Secretaries of State for Health, Wales, Northern Ireland, and Scotland. Working for patients. London: HMSO, 1989. (Cmnd 555.)

Secretaries of State for Social Services, Wales, Northern Ireland, and Scotland. Promoting better health. London: HMSO, 1987. (Cmnd 249.)

4 Macpherson G. Close vote and now a ballot on GPs' contract. Br Med f 1989;299:6. 